\title{
Accuracy of determination of real estate area
}

\author{
Agnieszka Bieda, Paweł Hanus, Elżbieta Jasińska, Edward Preweda \\ AGH University of Science and Technology, 30 Mickiewicza Av., 30-059 Krakow, Poland
}

\begin{abstract}
Accuracy of determination of real estate area has a great importance nowadays, both in real estate selling and in tax assessment and also in spatial planning. Present and used in the past methods of area determination of parcels, buildings and dwellings cause thatthe quantity of areas are not consistent and at present this situation gives many questions.

In the paper, discussion and analysis of methods of determination of areas of all types of estate in Poland, has been presented. Both methods used nowadays and used in the past has been showed here. In the relation to dwellings it has also been pointed, various provisions in force, within the range of computations of areas. For buildings in turn, it has been presented possible cases of determination of area of footprint of building and area of floor area (as sum of usable floor spaces) and areas of auxiliary premises. For land real estate, methods of determination areas of parcels used in the past together with their analysis of accuracy of areas and analytical methods used at present, have been presented. It has been pointed possible errors of analytical determined parcel area, as derivative of inaccuracy of determination of coordinates of boundary points and shape of parcel.

In the summarization, possible effects (both factual and legal) of erroneously revealed in documents areas or real estate, have been presented. It has also been presented possible changes in provisions of law, partially solving problem of inaccuracy of determination real estate area.
\end{abstract}

Keywords: property area; parcel; real estate; house; flat; accurancy.

\section{Introduction}

At present, accuracy and reliability of attributes describing real estate, is one of the most important factors, assuring correct real estate management. Besides determination of current legal status of real estate, accurate determination of the range of these rights gives guaranty of any next operations, connected with real estate. Unfortunately, both conditionings and technologies used for determination of areas of land parcels, buildings and dwellings cause, that obtained information are often inconsistent and unreliable. It causes many complications not only in such processes as real estate management, real estate valuation but also in real estate turnover itself.

In the paper, procedures of determination of real estate areas and their inaccuracy, have been pointed. It has also been presented inconsistencies in provisions in law, regulating methods of determination of area and its registration.

\section{Area of land real estate}

Historical determinants of cadastral managing, and also development of surveys technologies cause, that in contemporary cadastre are still functioning two terms for areas of parcels. There are: "cadastral area" - revealed in descriptive part of cadastre, and "surveying area" - computed on the basis of coordinates of boundary points of parcel [4]. These areas should be the same. Unfortunately in practice they are for the most part differ. It is especially frequent in case, when coordinates of boundary points have been captured by digitization of cadastral maps during cadastre modernization process. Thus, accordingly to [5], in case when accuracy of determination of coordinates of boundary points does not correspond to technical standards, cadastral area cannot be changed.

\footnotetext{
"This work is financed from funds for science realized at AGH University of Science and Technology, allocated for the year 2014"
}

Corresponding author: Edward Preweda. E-mail address: edward.preweda@agh.edu.pl

http://dx.doi.org/10.3846/enviro.2014.191

(C) 2014 The Authors. Published by VGTU Press. This is an open-access article distributed under the terms of the Creative Commons Attribution License, which permits unrestricted use, distribution, and reproduction in any medium, provided the original author and source are credited. 
Among reasons of discrepancies between area revealed in cadastre and area resulting from cadastral map, one can distinguish:

1) accuracy of data revealed in cadastre, resulting from:

a) rounded up area of parcel within rural cadastral units to $100 \mathrm{~m}^{2}$, according to former provisions [7],

b) standard deviations resulting from computation of area on traditional maps, resulting from imperfection of used methods (for example: graphic method, planimetric method and others), and also from scale of these maps,

2) accuracy of determination of boundaries in cadastral maps, resulting from standard deviation of:

a) boundaries measurement,

b) mapping boundaries on maps,

c) converting traditional maps to digital form (vector shape), including errors of scanning, transformation and vectorizationor accuracy of digitization.

In practice, only determined, fixed and measured in the field is the presence of parties, which have suitable surveying documentation, accepted by administrative decision or court verdict, gives certainty in the relation to area of parcel and location of its boundary points revealed in cadastre. Such boundaries became during delimitation process, both in administrative or court procedure and also during land consolidation. In case of unquestionable boundary, such status can also obtain during determination of boundaries, during updating, modernization or cadastre establishing. Such boundaries arecalled "legal boundaries" [3].

Unfortunately most of parcels do not fulfil presented above demands. The most frequent failure in this range is lack of activities of boundary determination in the presence of parties, or lack of documentation permitting on confirmation of steps establishing boundaries and documentation permitting on boundary restoration with demanded accuracy, describing in technical standards. Frequently the only document pointing on boundary course is cadastral map prepared in traditional form. On south-east Poland territories, such map is often derivative as former Austrian annexation cadastral map in scale $1: 2880$ or scaled up to $1: 2000$. In central or east Poland such maps are results of photogrammetric measurements, very often. Such boundaries are frequently called by term "boundaries according to factual status" [3].

The problem of discrepancies between cadastral and surveying areas of parcels is essential both in aspect of real estate turnover and in aspect of possible changes of attributes parcels, which are: area of parcel and coordinates of parcel boundary points. Lack on the abstract from cadastre land register such data as: inaccuracy of determination of area of parcel or location of boundary point cause that frequently both buyer and seller are not conscious that there is possibility of occurring discrepancies in size of parcel area. Discrepancies between cadastral and surveying area of parcel can identify with inaccuracy of determination of cadastral area of parcel. Area revealed in descriptive documents of cadastre, even if it differs from area determined from coordinates, yet this difference should not exceed error of determination of surveying area determined by coordinates.

Discrepancy between area revealed in cadastre and real area, determined on the basis of fixed in the presence of parties in the fields location of boundary points, is a very important matter. It is a very difficult task for surveyor to explain to the owner, why after delimitation procedure his parcel has less area than revealed in cadastre so far, from which he paid tax for many years. Owner frequently feels cheated, and contests qualifications of surveyor and office as well. Explanations, that boundary itself did not change, but changed only precision of its determination and way of determination of parcel area are frequently not sufficient. Such case can take place in situation, when owner bough recently real estate and paid for area revealed in cadastre. This area, after delimitation turned out incorrect. Additionally, former owner of parcel can also be accused. From this person, a new owner demands payback, resulting from "change" of real estate value.

It should be added in this place, that activities of boundary determination could be performed many years after real estate acquisition. The most frequent reason of undertaking activities of boundary determination is boundary dispute, need of investment location and its realization or will of selling real estate.

\section{Estimation of accuracy of determination of parcel area}

Problem concerning discrepancies in parcel area, depending from accuracy of determination of accuracy of determination of location boundary points, one can solve by approximate and precise method. Both methods of determination of difference between cadastral and surveying area use known Gauss formula. This formula has the following form:

$$
S=\frac{1}{2} \sum_{n=1}^{n}\left(\mathrm{X}_{i+1}-\mathrm{X}_{i-1}\right) Y_{i}
$$

where:

$S-$ parcel area

$X_{i}, Y_{i}$ - coordinates of " $i$ " point of boundary

After differentiating (1) one can get the following linear form:

$$
\mathrm{m}_{s}=m_{p} \sqrt{\frac{1}{8} \sum_{i=1}^{n}\left(X_{i+1}-X_{i-1}\right)^{2}+\left(Y_{i-1}-Y_{i+1}\right)^{2}}
$$


where:

$\mathrm{m}_{s}$ - standard deviation of parcel area,

$m_{p}$ - standard deviation of location of boundary point,

$X_{i}, Y_{i}$ - coordinates of " $i$ " - boundary point

In formula (2) have been taken equally standard deviations of coordinates $\mathrm{X}$ and $\mathrm{Y}$ of boundary points of parcel.

This formula has been used after [1] in some other form in [6], as:

$$
d P_{\text {max }}=m_{p} \sqrt{\frac{1}{8} \sum_{i=1}^{n} d_{i+1, i-1}}
$$

where:

$d P_{\max }$ - maximum (permissible) difference between parcel area, computed on the basis of measurements and revealed in cadastre, so far.

$m_{p}$ - mean square error of boundary point location,

$d_{i-1, i+1}$ - the shortest diagonal being in front of i-number point.

It is easy to see, that values under the square in formulas (2) and (3) are identical.

The key element of these formulas is standard deviation of boundary point location, which value is influenced by many factors. The most important is method of obtaining data concerning coordinates of boundary point.

One can remark, that in case of different boundary points and different shape of parcel, permissible discrepancy in parcel area will be also different. Analyzed cases show Fig. 1 .

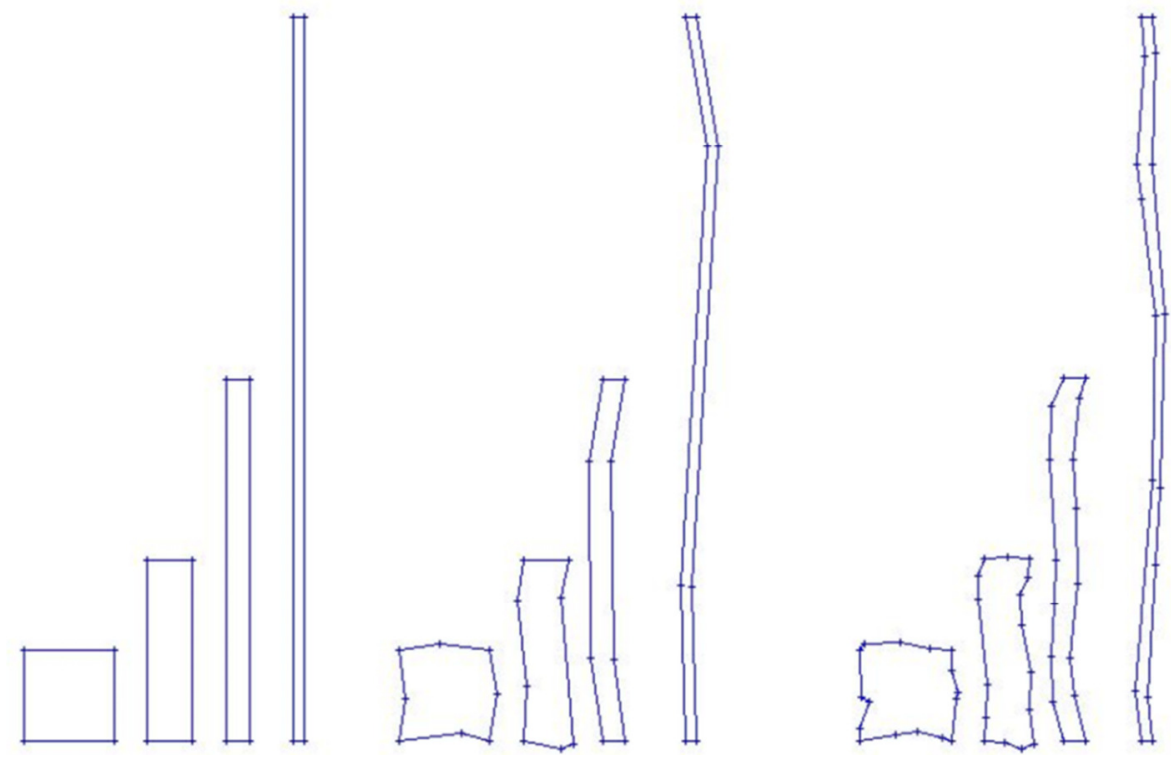

Fig. 1. Testing the influence of changes of parcel shape and number boundary points, on error of parcel area

Area of all examined parcels is equal to $10000 \mathrm{~m}^{2}$. The first four parcels have only 4 boundary points, where ratio of distances of longer parcel sides to their shorter sides is successive 1:1, 4:1, 16:1 i 64:1. The following eight parcels had similar shape, but number of boundary points was considerably increased (up 8 points -4 parcels and 16 points, the next 4 parcels). Results of analysis of errors computed according to formula (2) by various errors of boundary point location, shows Table 1.

The difference in parcel area increases together with elongation of parcel and with increasing of standard deviation of boundary point location.

As it was mentioned, presented above case is specific. Only in situation, where assumption of equally standard deviations and regular shape of parcel, expression on right side of formula (2) will be really equal to standard deviation of parcel area determination. These considerations are of essential importance in case of elongated parcels, which in southeast Poland, located especially on agricultural lands in some cadastral units, makes up the majority.

In order to make evaluation of accuracy of parcel area, well-known Gauss formula (1) was used. According to the law of variance propagation, one can write down.

$$
\mathrm{V}(P)=\mathbf{F}_{P}^{\mathrm{T}} \operatorname{Cov}(x, y) \mathbf{F}_{P}
$$

where:

$\mathrm{V}(P)$ - variance of considered area,

$\operatorname{Cov}(x, y)$ - matrix of covariance of coordinates of boundary points,

$\mathbf{F}_{P}$ - vector of partial derivatives of variables determined on the basis of formula (1). 
Table 1. Results of analysis of errors of area for parcel of area equal $10000 \mathrm{~m}^{2}$

\begin{tabular}{|c|c|c|c|c|c|c|c|}
\hline No & $\begin{array}{l}\text { Number of } \\
\text { points }\end{array}$ & $\begin{array}{l}\text { Perimeter of } \\
\text { parcel } \\
{[\mathrm{m}]}\end{array}$ & $\begin{array}{l}\text { with standard } \\
\text { deviation } \\
\mathrm{m}_{\mathrm{p}}=0,10 \mathrm{~m}\end{array}$ & $\begin{array}{l}\text { with standard } \\
\text { deviation } \\
\mathrm{m}_{\mathrm{p}}=0,30 \mathrm{~m}\end{array}$ & $\begin{array}{l}\text { with standard } \\
\text { deviation } \\
\mathrm{m}_{\mathrm{p}}=0,60 \mathrm{~m}\end{array}$ & $\begin{array}{l}\text { with standard } \\
\text { deviation } \\
\mathrm{m}_{\mathrm{p}}=1,50 \mathrm{~m}\end{array}$ & $\begin{array}{l}\text { with standard } \\
\text { deviation } \\
\mathrm{m}_{\mathrm{p}}=3,00 \mathrm{~m}\end{array}$ \\
\hline 1 & 4 & 400 & 10 & 30 & 60 & 150 & 300 \\
\hline 2 & 4 & 500 & 15 & 44 & 87 & 219 & 437 \\
\hline 3 & 4 & 850 & 28 & 85 & 170 & 425 & 850 \\
\hline 4 & 4 & 1625 & 57 & 170 & 339 & 849 & 1697 \\
\hline 5 & 8 & 405 & 9 & 26 & 52 & 131 & 262 \\
\hline 6 & 8 & 513 & 13 & 38 & 77 & 192 & 384 \\
\hline 7 & 8 & 855 & 23 & 69 & 137 & 343 & 686 \\
\hline 8 & 8 & 1631 & 47 & 141 & 281 & 703 & 1405 \\
\hline 9 & 16 & 415 & 7 & 21 & 42 & 105 & 211 \\
\hline 10 & 16 & 516 & 10 & 29 & 58 & 146 & 291 \\
\hline 11 & 16 & 859 & 16 & 49 & 98 & 245 & 490 \\
\hline 12 & 16 & 1629 & 33 & 98 & 195 & 488 & 977 \\
\hline
\end{tabular}

In practicezero values of covariance between coordinates of boundary points are taken wrongly. In case of traditional measurements (tachymetry), it should be taken into account such fact, that coordinates X,Y of specific point are correlated to each other [13]. As a rule, coordinates of all boundary points. Yet, these correlations have less importance for accuracy evaluation of area determination.

Substituting in formula (4) values of partial derivatives, with assumption that covariance between coordinates of different boundary points are zero, which can be written down:

$$
\mathrm{V}(P)=\frac{1}{4}\left[\begin{array}{c}
y_{n}-y_{2} \\
-\left(x_{n}-x_{2}\right) \\
y_{1}-y_{3} \\
-\left(x_{1}-x_{3}\right) \\
\cdots \\
\cdots \\
y_{n-1}-y_{1} \\
-\left(x_{n-1}-x_{1}\right)
\end{array}\right]^{\mathrm{T}}\left[\begin{array}{c:c:c:c}
\mathbf{C o v}\left(x_{1}, y_{1}\right) & \mathbf{0} & \mathbf{0} & \mathbf{0} \\
\hdashline \mathbf{0} & \mathbf{C o v}\left(x_{2}, y_{2}\right) & \mathbf{0} & \mathbf{0} \\
\hdashline \mathbf{0} & \mathbf{0} & \ldots & \mathbf{0} \\
\hdashline \mathbf{0} & \mathbf{0} & \mathbf{0} & \mathbf{C o v}\left(x_{n}, y_{n}\right)
\end{array}\right]\left[\begin{array}{c}
y_{n}-y_{2} \\
-\left(x_{n}-x_{2}\right) \\
y_{1}-y_{3} \\
-\left(x_{1}-x_{3}\right) \\
\cdots \\
\cdots \\
y_{n-1}-y_{1} \\
-\left(x_{n-1}-x_{1}\right)
\end{array}\right]
$$

Examine, on the example rectangular parcel, determination of error of area by various assumptions.

Take, that coordinates $\mathrm{x}$, $\mathrm{y}$ of boundary points $[\mathrm{m}]$, are shown in Table 2 :

Table 2. Coordinates used in numerical example

\begin{tabular}{lll}
\hline No & $\mathrm{X}[\mathrm{m}]$ & $\mathrm{Y}[\mathrm{m}]$ \\
\hline 1 & 0 & 0 \\
2 & 200 & 0 \\
3 & 200 & 20 \\
4 & 0 & 20 \\
\hline
\end{tabular}

and it was assumed that the value of boundary points location is the same and equals: $m_{p}= \pm 0,3 \mathrm{~m}$

According to formula (2), substituting taken values, we get $\mathrm{dP}_{\max }=42,6 \mathrm{~m}^{2}$. If we assumed, that standard deviation of determination of boundary point location is influenced equally by standard deviations $m_{x}, m_{y}$, but covariance between variables equal zero, then the same value $\mathrm{dP}_{\max }$ is got, by formula (4). In this case $m_{x}^{2}=m_{y}^{2}=\frac{m_{P}^{2}}{2}$

Substituting data to formula (5), we get: 


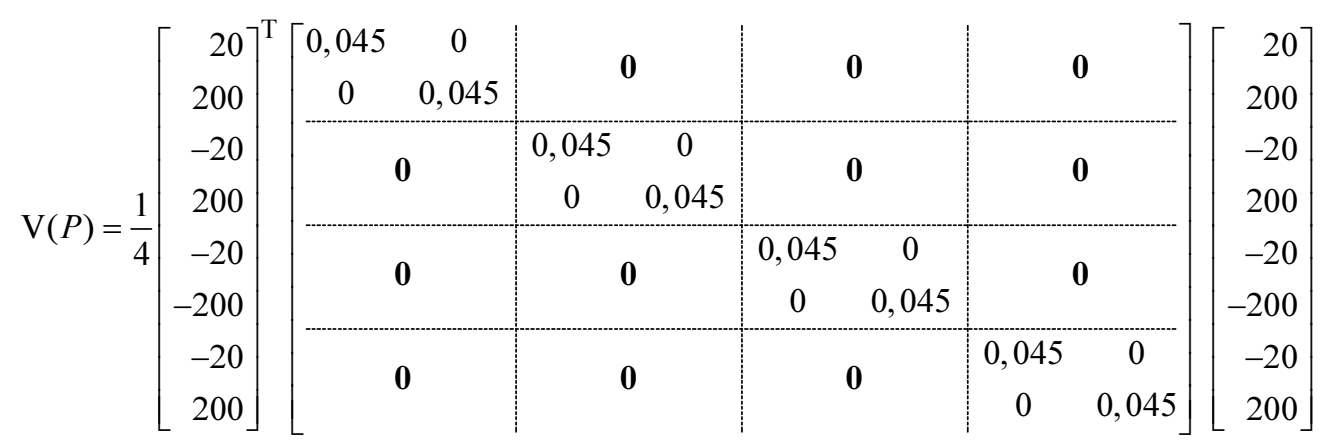

from $\mathrm{dP}_{\max }=\sqrt{\mathrm{V}(P)}=42,6 \mathrm{~m}^{2}$.

Yet, standard deviations $m_{x}, m_{y}$ are different, the most often. Let $m_{x}=0,10 \mathrm{~m}$. Then, in order to fulfil assumption $m_{p}= \pm 0,3 m, m_{y}=\sqrt{m_{P}^{2}-m_{x}^{2}}$ and $\operatorname{Cov}\left(x_{i}, y_{i}\right)=\left[\begin{array}{cc}0,01 & 0 \\ 0 & 0,08\end{array}\right]$.

In this case, substituting data to formula (4) we get: $\mathrm{dP}_{\max }=\sqrt{\mathrm{V}(P)}=56,6 \mathrm{~m}^{2}$.

But if we take a $m_{y}=0,10 m$ a $m_{x}=\sqrt{m_{P}^{2}-m_{y}^{2}}$, then $\operatorname{Cov}\left(x_{i}, y_{i}\right)=\left[\begin{array}{cc}0,08 & 0 \\ 0 & 0,01\end{array}\right]$, but $\mathrm{dP}_{\max }=20,8 m^{2}$.

In extreme cases, that is by assumption $m_{x}=0$ or $m_{y}=0$ we get respectively $d P_{\max }=60 \mathrm{~m}^{2}$ and $d P_{\max }=6,0 \mathrm{~m}^{2}$.

From presented analysis results, which is practical realization of criterion (2) it is nopossible in some cases, in spite of fulfilling assumption of standard deviation of boundary point's location. Very big influence on decision, if specific parcel fulfils criterion (2), has not only inaccuracy of boundary points location, but also lands configuration itself, shape of parcel and its location in relation to coordinate system.

Because determination of full covariance matrix, in case of new traditional measurements, does not make any trouble, it is recommended to apply precise evaluation of accuracy of determination of area.

\section{Usable area of buildings and dwellings}

Law provisions, concerning computation of usable area, has evolved over the last 32 years. In 1971, the standard PN 70/B-02365 "Area of buildings. Classification, terms and rules of quantity survey", was implemented. Although in 1977, a new standard PN-ISO 9836:1997, was implemented, legislator still used provisions which were not in operation [8].

Such situation caused, that two different standards were used paralelly. According to them, one could make measurements of usable area and other elements of buildings and dwellings. Yet, parallel using these standards caused quite significant differences between measured elements, implying various consequences. It will be mentioned about them in the further part of the paper. These differences, of essential character, have been syntetically presented in Table 3 .

Table 3. Differences in methods of computation of usable area, according to two parallel standards (in years 1997-2012)

\begin{tabular}{|c|c|c|}
\hline Survey attribute & $\begin{array}{l}\text { According standard } \\
\mathrm{PN}-70 / \mathrm{B}-02365\end{array}$ & $\begin{array}{l}\text { According standard } \\
\text { PN-ISO 9836:1997 }\end{array}$ \\
\hline Accuracy of writing area & $0.1 \mathrm{~m}^{2}$ & $0.01 \mathrm{~m}^{2}$ \\
\hline Level where survey is made & $1.00 \mathrm{~m}$ over floor & On the level of floor \\
\hline Condition of estate during survey & Raw & Completed \\
\hline Niches in walls of area over $0.1 \mathrm{~m}^{2}$ & Added to area of room & Omitted \\
\hline $\begin{array}{l}\text { Pilasters and other cornices of area } \\
\text { over } 0.1 \mathrm{~m}^{2}\end{array}$ & $\begin{array}{l}\text { Reduced from area of room and added to area of } \\
\text { construction }\end{array}$ & Not reduced \\
\hline $\begin{array}{l}\text { Part of room of height more than } \\
\text { level of specific floor }\end{array}$ & Included to the whole area & Separated \\
\hline Area of floor with slope ceiling & $\begin{array}{l}\text { Heights over } 2.20 \mathrm{~m} \\
\text { are counted as } 100 \% \text {, } \\
\text { heights from } 1,40 \text { to } 2,20 \mathrm{~m} \\
\text { are counted as } 50 \% \text {, } \\
\text { heights less than } 1,40 \mathrm{~m} \text { are not included to area of room }\end{array}$ & $\begin{array}{l}\text { Area of room is computed whole according to its floor area, } \\
\text { but it is separated into two parts: par of height } 1.90 \mathrm{~m} \text { and } \\
\text { more and part of height below } 1.90 \mathrm{~m} \text {, which can be } \\
\text { classify exclusively to supplementary area }\end{array}$ \\
\hline $\begin{array}{l}\text { Outer areas which are not closed } \\
\text { from all sides, accessible from } \\
\text { specific room }\end{array}$ & Not included to area (neither flat nor business premise) & $\begin{array}{l}\text { Included to area of flat nor business premise, showing } \\
\text { separately not covered surfaces (balconies, terraces) and } \\
\text { covered surfaces (loggies) }\end{array}$ \\
\hline
\end{tabular}


These discrepancies could seem rather small. Nevertheless, taking into account unit price for $1 \mathrm{~m}^{2}$ space of premise, which is at level 7000 PLN (1750 EUR), one should ask question if they are neglected or not. Below, an example of way of computing such area, resulting differences reaching $3 \%$, that is $1.8 \mathrm{~m}^{2}$. It corresponds to 12600 PLN (3150 EUR). Area computed according to PN - 70/B-02365 is $53.6 \mathrm{~m}^{2}$, and according to $\mathrm{z}$ PN-ISO 9836:1997 is $51.8 \mathrm{~m}^{2}$ [14]. It is obvious, that one and forever measured up buildings and dwellings are not objects of survey again. So, their original condition will be the basis not only for determination of real estate prices but also for computation of interest in common part of building and for computation of real estate tax [9]. The latter is depended in Poland from real estate area not just from its value.

Only 2012 year brought clear provisions as far as newly dwellings are concerned. They are Act - about protection of purchaser of single-family house - from 2011 [15] and Ordinance - in case of detailed range and form of building project from 2011 [16]. Both provisions entered into force in 2012. The Act [15] tells, that developer agreement should way of survey of usable area of dwelling. On the other hand Ordinance assumes, that for computation of usable area of newly buildings one should use standard PN-ISO 9836:1997. For investments started formerly, or superstructure or redevelopment of buildings, previous provisions are still in use. Given in Ordinance [16] definition of dwelling excludes from computations areas of terraces, balconies and loggies, as not separated by solid walls rooms. Ordinance specifies and uniforms also the way of computing areas of rooms with slope ceilings. According to it, area is taken as $100 \%$ in the part of room of height being over $2.20 \mathrm{~m}$, and it is taken as $50 \%$ in the part of room of height being from $1.40 \mathrm{~m}$ to $2.20 \mathrm{~m}$. It collides with standard PN-ISO 9836:1997, where separation was to be made at height of $1.90 \mathrm{~m}$.

It is worth mentioning that according to altered Ordinance - in case of cadastre [5], in cadastre are registered (in relation to dwellings), both area determined from quantity surveys and usable area given in building project. Factual differences between them can result from:

- taking into account niches of areas of $0.1 \mathrm{~m}^{2}$,

- computation area including plasters or not, covered on walls, or not,

- differences caused by slope ceilings.

Usable area revealed in cadastre should be determined on the basis given in Act [11] with accuracy of $0.01 \mathrm{~m}^{2}$. Discrepancy in determination area could be in many cases the reason of difference in resulted areas. Taking into account, that provisions of altered Ordinance [16] will enter into force in 2016, December the 31st, it is difficult to determine clearly, if it will influence on building acceptance or not.

\section{Conclusions}

As it is proved in the article, suitable determination of area of real estate is troublesome, many time. Various provisions, used in the past and nowadays and various methods and equipmentcause that obtained results are not consistent.

The most important conclusions, connected with computation of area of real estate are shown below.

In case of land real estate:

- it is necessary to take into account, both in real estate turnover and in cadastre, inaccuracy of determination of parcel area,

- limit error of parcel area one can present in simplified way for parcels, which coordinates of boundary points have been obtained by vectorization of raster map,

- limit standard deviation of parcel area, which coordinates of boundary points have been obtained by direct field measurement one should determine by precise method, differentiating standard deviations and taking into account the shape of parcel,

- bothstandard deviation of parcel area and errors of location of boundary points should be presented in documents accessible to parties in real estate turnover.

- In case of usable area of buildings and dwellings:

- various standards of computation of usable area of dwellings caused big differences, revealed in documentation of these dwellings. Unfortunately, unification of provisions in 2012, do not concern these dwellings which area were determined before 2012 .

- various definitions of usable area in provisions being in force to April, the 29th 2012, led to abuses from sellers of real estate and it had repercussions on real estate market [12]. It was also the reason of discrepancies between usable area given in architectural and construction documentation,

- necessity of revealing in cadastre usable area of buildings obtained by quantity survey and revealed in project documentation may cause, by using various methods of computation of area, big discrepancies,

- differences in revealed usable area make difficult correct valuation of dwellings and buildings [12] and also correct computation of real estate tax [10],

- changes in provisions of the law connected with computation of usable area will improve situation on real estate market, but it will be long-lasting process.

It is worth mentioning in this place that public guarantee of land register in Poland concern only real rights. Guarantee does not include data concerning factual status of real estate, obtained from cadastre that is also area of real estate. So, there is not possibility in this case protection of rights of purchaser considering inaccurate determination of acquired real estate in respect of guarantee. It concernsbothlands and buildings and dwellings. 


\section{References}

[1] Doskocz, A. P. 2005. Analiza doktadności obliczenia pola powierzchni ze wspótrzędnych. Przegląd Geodezyjny 4/2005.

[2] Hanus, P. 2006. Ocena przydatności dokumentacji byłego katastru austriackiego dla potrzeb prac geodezyjnych. Rozprawa doktorska AGH Kraków 2006. Praca niepublikowana.

[3] Hycner, R. 2004. Podstawy katastru. Uczelniane Wydawnictwa Naukowo-Dydaktyczne. AGH Kraków 2004

[4] Instrukcja techniczna G-5 - Ewidencja gruntów i budynków - wytyczne techniczno- organizacyjne, GUGiK Warszawa 2003.

[5] Rozporzqdzenie Ministra Rozwoju Regionalnego i Budownictwa z dnia 29 marca 2001 r. w sprawie ewidencji gruntów i budynków (Dz. U. z 2001 r. $\mathrm{Nr} 38$ poz. 454)

[6] Rozporzqdzenie Ministra Spraw Wewnętrznych i Administracji z dnia 9 listopada 2011 r. w sprawie standardów technicznych wykonywania pomiarów sytuacyjnych $i$ wysokościowych oraz opracowywania i przekazywania wyników tych pomiarów do państwowego zasobu geodezyjnego $i$ kartograficznego (Dz. U. z 2011 r. Nr 263 poz. 1572)

[7] Zarzqdzenie Ministrów Rolnictwa i Gospodarki Komunalnej z dnia 20 lutego 1969 r. w sprawie ewidencji gruntów (MP Nr 11 , poz.98 z 1969 r.)

[8] Korzeniewski W.:Obliczanie powierzchni i kubatury budynków. Warszawa 2004, Centralny Ośrodek Informacji Budownictwa

[9] Ustawa z dnia 12 stycznia 1991 r. o podatkach i opłatach lokalnych ( Dz.U. Nr 9 z 1991r., poz. 31)

[10] Rozporzadzenie Ministra Finansów z dnia 22 kwietnia 2004 r. w sprawie ewidencji podatkowej nieruchomości (Dz. U. Nr 107 z 2004 r., poz. 1138)

[11] Ustawa z dnia 21 czerwca 2001 r. o ochronie praw lokatorów, mieszkaniowym zasobie gminy i o zmianie Kodeksu cywilnego ( Dz.U. Nr 71 z 2001r., poz. 733)

[12] Jasińska, E. 2012. Chosen Statistical Method In Real Estate Market Analysis - monografia, Kraków 2012

[13] Preweda, E. 2013. Rachunek wyrównawczy $\Rightarrow$ modele statystyczne [Adjustment computations $\Rightarrow$ models] . Kraków, Wyd. PROGRES, 2013 r., ISBN: 978-83-938093-0-1

[14] http://www.pkn.pl/sites/default/files/prezentacja_dr_inz._arch.a.starzyk.pdf

[15] Ustawa o ochronie praw nabywcy lokalu mieszkalnego lub domu jednorodzinnego z dnia 16 września 2011 r. (Dz. U Nr 232 z 2011 r. poz.1377)

[16] Rozporzqdzenie Ministra Transportu, Budownictwa i Gospodarki Morskiej z dnia 25 kwietnia 2012 r. w sprawie szczegółowego zakresu i formy projektu budowlanego (Dz. U. z 2012 r. poz. 462) 